\title{
Mediastinal paraganglioma causing spinal cord compression
}

\author{
M. G. REYES, ${ }^{1}$ R. FRESCO, AND M. E. BRUETMAN \\ From the Departments of Pathology (Neuropathology), Experimental Pathology, and Neurology, \\ Mount Sinai Hospital Medical Center, Chicago, Illinois, USA
}

SUMMARY An invasive paraganglioma of the posterior mediastinum caused spinal cord compression in a 31 year old woman. Electron microscopic examination of the paraganglioma invading the epidural space revealed numerous dense-cored granules in the cytoplasm of the tumour cells. We are reporting this case to present the ultrastructure of mediastinal paraganglioma, and to call attention to an unusual cause of spinal cord compression.

Three cases of spinal cord compression from invasive paraganglioma of the mediastinum have been reported in the literature (Duncan and McDonald, 1951; Maier and Humphreys, 1958; Haber, 1964). This report documents a fourth case, and describes the ultrastructure of this rare neoplasm.

\section{Case report}

In 1964 a 24 year old woman without symptoms had a routine chest radiograph which disclosed a mass $2.5 \mathrm{~cm}$ in diameter in the right posterior mediastinum beside the third costovertebral junction. In 1966 a repeat radiograph of the chest showed the mass to be $5 \mathrm{~cm}$ in diameter. When the posterior mediastinum was explored through a right thoracotomy, it was found that a retropleural, multilobulated paraganglioma had eroded the head and neck of the second, third, and fourth ribs on the right side. The tumour was excised, except for a small portion lying deep in the third intercostal space in the paravertebral gutter.

In December 1970 the patient developed sudden, sharp pain in the lumbosacral region; she subsequently complained of weakness in her right leg. Two months later her left leg also became weak, and she experienced a burning sensation in both legs. Three weeks before admission to hospital on 20 April 1971, she noted urgency and urinary incontinence.

Physical examination revealed blood pressure of $130 \mathrm{mmHg}$, pulse rate of 84 beats per minute, and

\footnotetext{
${ }^{1}$ Address for reprint requests: Dr M. G. Reyes, Department of Neuropathology, Mount Sinai Hospital Medical Center, Chicago, Illinois 60608, USA.

Accepted 20 October 1976
}

temperature of $37.2^{\circ} \mathrm{C}$. Apart from uterine enlargement and the presence of fetal heart sounds consistent with the fifth month of pregnancy, the generato physical examination was normal. Neurologica? examination showed spastic paraparesis, with more involvement of the right than left leg. Gait wa spastic, slow, and unsteady. Muscle stretch reflexes were hyperactive, and bilateral ankle clonus could be induced. Babinski's sign was present on both sideso Pain sensation was diminished below the T4 derma tome but position and vibratory senses were normafol Examination of the upper limbs, cranial nerves, and mental state gave normal findings.

The complete blood count, blood glucose and urea nitrogen, serum electrolytes, and liver function tests were normal. Cerebrospinal fluid from the lumbar subarachnoid space was clear and colourless, and contained 1,500 red blood cells per cu. $\mathrm{mm}$, nine polymorphonuclear leucocytes per $\mathrm{cu} . \mathrm{mm}$, and $1.25 \mathrm{~g} / \mathrm{l}$ of protein.

Radiography of the thoracic spine showed destruction of the right pedicle of the T4 vertebra. Myelography demonstrated a partial block at the level of the body of the T4 vertebra. Surgical exposure of the spinal canal through laminectomy of the T3-5 vertebrae revealed an epidural tumour which was pushing the spinal cord posteriorly and to the left, and was invading the body and pedicles of the T3-5 vertebrae. Most of the tumour in the epidural space and bony structures was excised but no attempt was made to remove the portion of the tumour emerging from the right paravertebral gutter.

After surgery, the patient regained control of her bladder sphincter and full strength of her lower limbs. The sensory symptoms and findings were no longer 
present. Five months later, she gave birth to a fullterm, normal baby girl. Neurological examination of the patient at that time was normal except for hyperactive muscle stretch reflexes in her legs.

\section{PATHOLOGICAL FINDINGS}

The tumour excised from the epidural space consisted of irregular reddish-brown fragments of tissue. Histopathological examination disclosed a cellular neoplasm with compressive changes. The tumour cells had indistinct borders, eosinophilic cytoplasm, and round-to-oval hyperchromatic or pyknotic nuclei. The cells appeared in groups (zellballen) or cord-like arrangements, and were separated by thin vascular septa or thickened hyalinised fibrous tissue. The neoplasm had infiltrated several nerve bundles and bone fragments. Epoxy-embedded thick sections stained by methylene blue and carbol fuchsin clearly showed the zellballen arrangement (Fig. 1), as well as several mast cells in the stroma. Electron microscope examination demonstrated tightly packed tumour cells surrounded by capillary endothelial cells, pericytes, and collagen fibrils. The cytoplasm of the tumour cells contained numerous mitochondria and dense-cored granules (Figs. 2 and 3). These granules were distributed throughout the cytoplasm, but in some tumour cells they were concentrated around the Golgi zone (Fig. 4). No sustentacular cells, synaptic vesicles, or terminal axonal structures were found.

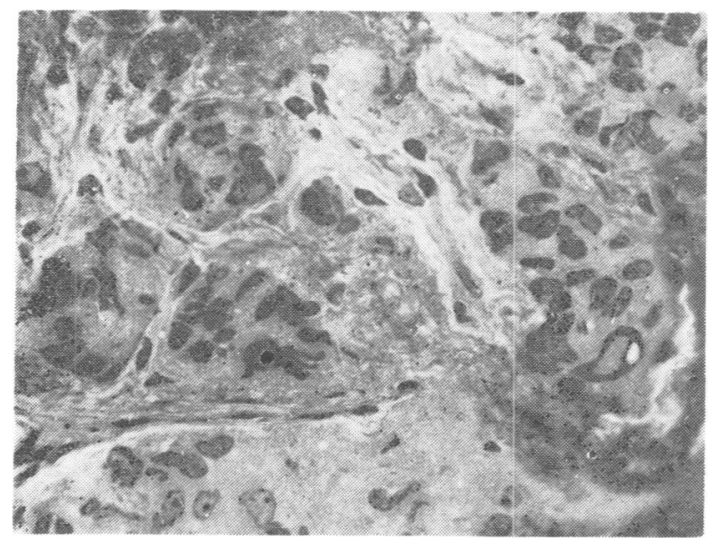

Fig. 1 Paraganglioma from epidural space showing groups of cells (zellballen) separated by fibrovascular stroma. (Methylene blue and carbol fuchsin stain, original magnification $\times 640$.)

\section{Comment}

Paragangliomas of the mediastinum-also called non-chromaffin paraganglioma (Duncan and Mc-

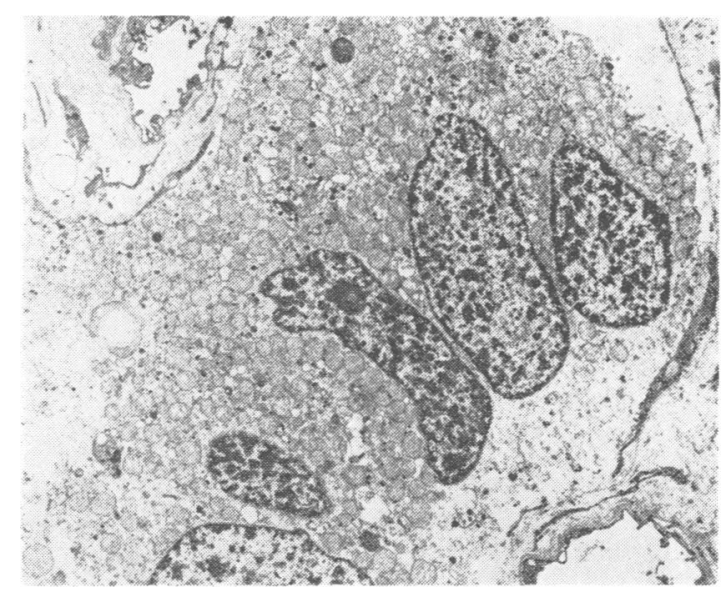

Fig. 2 Group of tumour cells with indistinct borders between two blood vessels. The cytoplasm of the tumour cells is filled with mitochondria and contains several electron dense-cored granules. (Original magnification $\times 6,000$.)

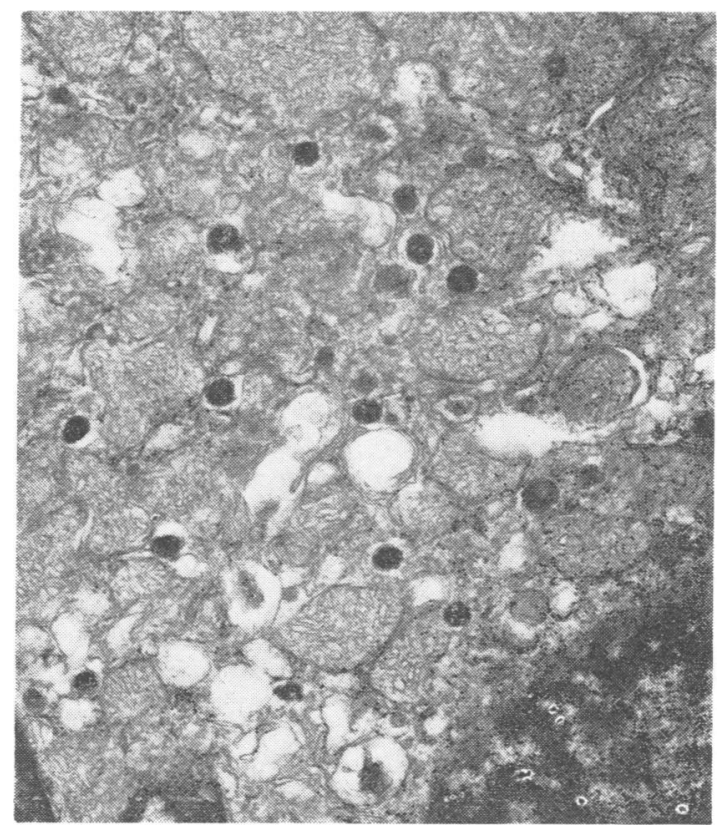

Fig. 3 Detail of tumour cell showing numerous membrane-bound, electron dense-cored granules interspersed among mitochondria. A portion of the cell nucleus (lower right corner) demonstrates nuclear pores. (Original magnification $\times 35,000$.)

Donald, 1951), chemodectoma (Duncan and McDonald, 1951; Mendelow and Slobodkin, 1957; Haber, 1964), aortic body tumour (Mendelow and 


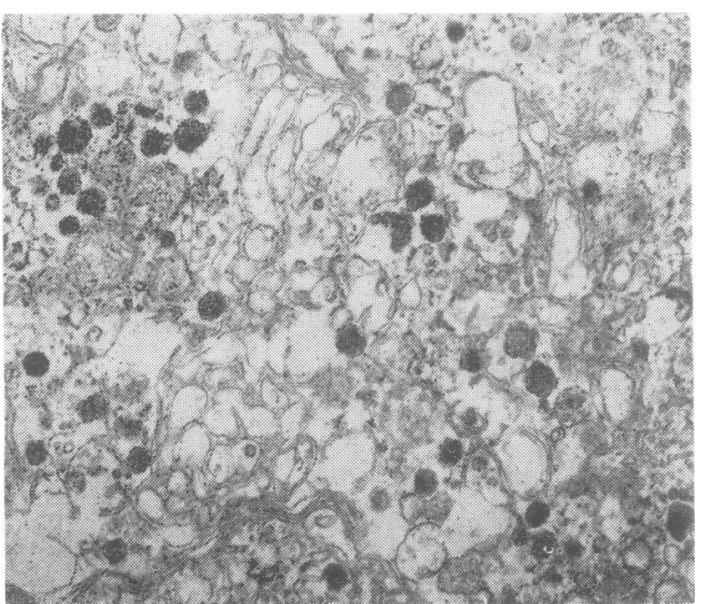

Fig. 4 Golgi's zone of a tumour cell showing many secretory granules. (Original magnification $\times 35,000$.)

Slobodkin, 1957), and intrathoracic pheochromocytoma (Maier and Humphreys, 1958; Green and Bassett, 1961 ; Luna et al., 1963; Cuetto et al., 1965)are rare neoplasms of the paraganglion cells which arise from the neural crest and migrate with the ganglia of the autonomic nervous system (Pack et al., 1962; Glenner and Grimley, 1974). These round or lobulated, encapsulated, soft tumours are found along the sympathetic chain in the paravertebral gutter in the posterior mediastinum, or along the branches of the vagus nerve and the ascending aorta and trunk of the pulmonary artery in the anterior mediastinum.

Paragangliomas of the posterior mediastinum are often associated with chronic hypertension (Cone $e t$ al., 1957; Maier and Humphreys, 1958), but some tumours have also been found incidentally at necropsy (Green and Bassett, 1961), and in asymptomatic patients (Cuetto et al., 1965). These tumours rarely metastasise to distant sites (Pack et al., 1962), but they can invade the epidural space and cause spinal cord compression, as shown by our case and by three other cases in the literature (Duncan and McDonald, 1951; Maier and Humphreys, 1958; Haber, 1964) (Table). The cases listed in the Table are young or middle-aged patients in whom the diagnosis of paraganglioma of the posterior mediastinum was made five to 14 years before the onset of clinical signs of spinal cord compression. Radiological examination of the thoracic spine showed signs of bone destruction in all the patients. Surgical treatment benefited two patients with incomplete myelopathy (cases 2 and 4 ), but not one patient with complete loss of spinal cord function below the level of compression (case 3).

The cytoplasmic dense-cored granules in the tumour cells of our case of paraganglioma of the mediastinum appear to be characteristic of paragangliomas as we have seen identical granules in paragangliomas of the carotid body, larynx, and glomus jugulare (unpublished observations). Other authors have also reported finding similar granules in other extra-adrenal paragangliomas (Glenner and Grimley, 1974), but, to our knowledge, the ultra= structure of mediastinal paraganglioma has not beet reported previously. The presence of dense-core granules in our case correlates with the finding of catecholamines in other paragangliomas of the posterior mediastinum (Cone et al., 1957; Luna et al. 1963).

\section{References}

Cone, T. E., Allen, M. S., and Pearson, H. A. (1957) Pheochromocytoma in children. Pediatrics, 19, 44-56.

Cuetto, J. C., McFee, A. S., and Bernstein, E. F. (1965). Intrathoracic pheochromocytoma. Diseases of the Chest , 48, 539-544.

Duncan, D. K., and McDonald, J. R. (1951). Chemodectoma ('non-chromaffin paraganglioma'). American Journal of Clinical Pathology, 21, 515-520.

Table Clinical findings of invasive paraganglioma of the posterior mediastinum causing spinal cord compression

\begin{tabular}{|c|c|c|c|c|c|c|c|c|c|}
\hline Authors & $\begin{array}{l}\text { Age } \\
(y r)\end{array}$ & $\operatorname{Sex}$ & Location & $\begin{array}{l}\text { Interval* } \\
(y r)\end{array}$ & $\begin{array}{l}\text { Sensory } \\
\text { level } \\
(\text { dermatome })\end{array}$ & Weakness & $\begin{array}{l}\text { Spine } \\
\text { radiograph }\end{array}$ & Treatment & Result \\
\hline 1. Duncan and McDonald & 46 & $\mathbf{F}$ & $\begin{array}{l}\text { right side; } \\
\text { T6-7-8 vertebrae }\end{array}$ & 14 & T5 & Paraparesis & $\begin{array}{l}\text { Collapsed } \\
\text { T7 vertebra }\end{array}$ & None & No change \\
\hline 2. Maier and Humphreys & 22 & $\mathbf{M}$ & $\begin{array}{l}\text { right side; } \\
\text { T6 vertebra }\end{array}$ & 8 & T5 & Paraparesis & $\begin{array}{l}\text { Destruction } \\
\text { T5 vertebra }\end{array}$ & Surgery & $\begin{array}{l}\text { Improved } \\
\text { ( } 3 \text { months) }\end{array}$ \\
\hline 3. Haber & 24 & $\mathbf{F}$ & $\begin{array}{l}\text { left side; } \\
\text { T8 vertebra }\end{array}$ & 5 & T8 & Paraplegia & $\begin{array}{l}\text { Destruction } \\
\text { T9 vertebra }\end{array}$ & $\begin{array}{l}\text { Surgery and } \\
\text { radiation }\end{array}$ & No change \\
\hline 4. Present case & 31 & $\mathbf{F}$ & $\begin{array}{l}\text { right side; } \\
\text { T3-4-5 vertebrae }\end{array}$ & 5 & T4 & Paraparesis & $\begin{array}{l}\text { Destruction } \\
\text { T5 right } \\
\text { vertebral } \\
\text { pedicle }\end{array}$ & Surgery & $\begin{array}{l}\text { Improved } \\
\text { (5 months) }\end{array}$ \\
\hline
\end{tabular}

$\mathbf{T}=$ Thoracic

* = Time between diagnosis of mediastinal paraganglioma and onset of spinal cord compression 
Glenner, G. G., and Grimley, P. M. (1974). Tumors of the extra-adrenal paraganglion system (including chemoreceptors). Atlas of Tumor Pathology, Fascicle 9, Second Series. Armed Forces Institute of Pathology: Washington, D.C.

Green, W. O., and Bassett, F. H. (1961). Intrathoracic pheochromocytoma. American Journal of Clinical Pathology, 35, 142-146.

Haber, S. (1964). Retroperitoneal and mediastinal chemodectoma. American Journal of Roentgenology, 92, 1029-1041.

Luna, R., Katz, I., and Ernst, R. W. (1963). Intrathoracic pheochromocytoma. Archives of Surgery, 87, 369-373.

Maier, H. C., and Humphreys, G. E. (1958). Intrathoracic pheochromocytoma. Journal of Thoracic Surgery, 36, 625-641.

Mendelow, H., and Slobodkin, M. (1957). Aortic body (chemodectoma) tumor of the mediastinum. Cancer, 10, 1008-1014.

Pack, G. T., Horning, E. D., and Ariel, I. M. (1962). Tumors of the sympathetic ganglia and the paraganglionic cells. In Pack, G.T., Ariel, I.M. (Editors). Treatment of Cancer and Allied Diseases, 2nd edn, vol. 2, pp. 259-271. Hoeber: New York. 